\title{
Konsep Menderita Menurut Kolose 2:24 dan Implikasinya Bagi Orang Kristen
}

\author{
Edward Simanjuntak* Eko Prasetyo, ${ }^{2}$ Haposan Simanjuntak, ${ }^{3}$ Rohantjen Girsang ${ }^{4}$ \\ Prodi Teologi STT Real Batam \\ Prodi Teologi STT Real Batam \\ Prodi Teologi STT Real Batam \\ juntakedward17@gmail.com
}

\begin{abstract}
The culmination of all the work of Christ in the world most frequently brought up against Christianity in modern times is suffering. The context of suffering that Paul mentioned in Colossians seems to suggest that Paul's suffering fulfilled Christ's suffering not by adding something to the value of Christ's suffering, but by conveying that suffering to those who were intended to be blessed through it. But then the question arises, how could something be lacking in the sufferings of Christ? Is not Christ's suffering and death sufficient? Actually, Paul intended not to reduce the meaning of suffering to Christ but rather to the fulfillment of Christ's deepest personal secrets in Paul. This paper uses an eclectic approach by combining all aspects of unanimity, philosophically, theoretically and psychologically
\end{abstract}

Keywords: Christ,Suffering, Paul, Christianity

\begin{abstract}
Abstrak
Puncak dari seluruh karya Kristus di dalam dunia yang paling sering dilontarkan terhadap Kekristenan di jaman modern ini adalah penderitaan. Konteks penderitaan yang Paulus sebutkan di dalam Kolose seolah menyarankan bahwa penderitaan Paulus menggenapkan penderitaan Kristus bukan dengan menambahkan sesuatu pada nilai penderitaan Kristus itu, tetapi dengan menyampaikan penderitaan itu kepada orang-orang yang memang dimaksudkan hendak diberkati melaluinya. Namun kemudian timbul pertanyaan, bagaimana mungkin ada sesuatu yang kurang dalam penderitaan Kristus? Bukankah penderitaan dan kematian Kristus sudah sangat memadai ? Sebenarnya Paulus bermaksud bukan untuk mengurangi makna penderitaan pada Kristus namun lebih kepada peggenapan rahasia Kristus terdalam secara personal dalam diri Paulus. Paper ini menggunakan pendekatan eklektik yaitu dengan penggabungan semua aspek kebulatan makna, secara filosofis, teoritis dan psikologis

Kata kunci: Kristus, Penderitaan, Paulus, Kekrisrtenan,
\end{abstract}

\section{PENDAHULUAN}

Paulus dan surat-suratnya merupakan "lahan" studi yang mungkin tidak akan pernah selesai digarap hingga kapan pun. Sebagaimana yang diutarakan beberapa ahli Perjanjian Baru, paling tidak ada dua alasan historis yang bisa dikemukakan untuk klaim ini, yaitu: pertama, signifikansi Paulus dan surat-suratnya dalam sejarah awal kekristenan hingga saat ini. Sebagaimana dituliskan oleh Frank Thielman,

Historically speaking ... Paul is both the first and greatest Christian theologians. This is true not because he was the first Christian to engage in theological reflection, but he 
was the first to devote a considerable portion of his life to this kind of reflection, to teaching his theological convictions to others, and to writing them down. He is the greatest Christian theologians ... because of his widespread influence, particularly after the canonization of his letters in the second century"1

Juga bisa ditambahkan bahwa secara historis, hampir separoh PB berasal dari Paulus dan ia juga merupakan misionaris Gereja mula-mula yang paling banyak merintis pos-pos pelayanan di daerah-daerah gentiles. Kedua, kesulitan-kesulitan historis yang kita hadapi saat meneliti mengenai Paulus dan surat-suratnya. Mengenai hal ini, Paul W. Barnett menyatakan, "Paul is an enigmatic figure because we have more questions about him than answers." Surat-surat Paulus pun menghadirkan kesulitan yang tidak kalah sulitnya dengan penelitian historis mengenai figur Paulus. Morna D. Hooker menyatakan bahwa saat membaca surat-surat Paulus, kita seperti mendengar percakapan seseorang yang sedang menelepon. Kita hanya mendengar pembicaraan tersebut dari orang yang berada di dekat kita, namun lawan bicaranya di ujung sana tidak kita ketahui persis isi pembicaraannya. $^{3}$

Yates merangkum lima pandangan yang berbeda terhadap teks ini dari beberapa pihak: a) pihak Roma Katolik yang percaya bahwa penderitaan Paulus merupakan suplemen bagi penderitaan Kristus; b) J.B. Lightfoot yang di satu sisi sadar akan kelemahan pandangan Katolik Roma tersebut namun tetap berpandangan bahwa dalam pengertian tertentu kita dapat berbicara bahwa penderitaan Kristus perlu disuplemen; c) Chrysostom, Calvin, Radford, dan Thornton menafsirkan ayat ini dalam terang kesatuan mistis dengan Kristus; d) Erns Best merujuk kepada "Messianic birth-pangs" sebagai solusi terbaik; dan e) C.F.D. Moule mengusulkan "the corporate Christ" sebagai solusinya. Yates mengikuti pandangan Moule. ${ }^{4}$

Bolkestein nampaknya menggunakan pendekatan "kesatuan dengan Kristus" terhadap teks tersebut. Menurutnya, dalam persekutuannya dengan Kristus, Paulus telah banyak menderita akan tetapi masih ada yang kurang. Jadi bukan penderitaan Kristus yang masih kurang melainkan penderitaan Paulus. Penderitaan yang masih kurang itu sedang digenapi dalam tubuh Paulus dalam penjara. Jadi sekarang penderitaan yang dialami Paulus adalah bayangan penderitaan Kristus. Penganiayaan yang dialami dalam persekutuan Kristus membawa pengharapan yang besar, sehingga menjadi sumber sukacita. Sebab barang siapa mempunyai tanda-tanda penganiayaan Kristus suatu saat akan memiliki kemuliaan bersama-sama dengan Kristus (1 Ptr 4:13). ${ }^{5}$ Tiga tahun setelah publikasi artikel

\footnotetext{
${ }^{1}$ Frank Thielman, Theology Of The New Testament: A Canonical And Synthetic Approach (Grand Rapids Michigan: Zondervan, 2005).

${ }_{2}^{2}$ Paul W. Barnett, Paul, Missionary Of Jesus (Grand Rapids, Michigan: Eerdmans, 2008).

${ }^{3}$ Morna D. Hooker, “Were There False Teachers in Colossae?," In Christi and Spirit in the New Testament, ed. B. Lindars and S.S. Smaley (Cambridge: Cambridge University Press, 1973).

${ }^{4}$ Yates Roy, “A Note On Colossians 1:24,” The Evangelical Quarterly XLII, no. 2 (1970): 89-92.

${ }^{5}$ M. H. Bolkestein, Surat Kiriman Kepada Orang Kolose (Jakarta: BPK Gunung Mulia, 1950).
} 
Yates, L. Paul Trudinger mempublikasikan sebuah artikel singkat responsif terhadap artikel Yates. ${ }^{6}$ Trudinger mengikuti kesimpulan Yates, namun ia memberikan penjelasan lanjutan mengenai gagasan "the corporate Christ" yang bertolak dari Filipi 3:9-11. ${ }^{7}$ Penjelasan lanjutan dari Trudinger kemudian dikembangkan secara lebih detail oleh Andrew Perriman. ${ }^{8}$ Walau sebenarnya dua tahun sesudah publikasi artikel Trudinger, Richard J. Bauckham telah memperlihatkan kelemahan penjelasan lanjutan dari Trudinger yang tentunya berimplikasi pada kesimpulan eksegetis yang diterima Trudinger dari Yates dimana kesimpulan ini paling umum di anut." Menurut Bauckham, kelemahan dari pandangan mayoritas ini hanya bisa "ditutupi" dengan memberikan perhatian terhadap motif apokaliptik di balik Kolose 1:24. ${ }^{10}$

This paper describes the problems that occur and can be scientifically proven or can be investigated by methodological, hermeneutic, exegesis approaches. In this introduction, a thesis will be explained which will be described or examined to answer issues, and issues are surrounding theology, Christian and pastoral education which can be interpreted in an argumentative and quantitative, qualitative and other measurable data analysis.

\section{METODE}

Adapun metode riset yang digunakan dalam rangka mendapatkan sumber-sumber untuk penulisan tesis ini adalah metode kualitatif. Metode ini nantinya teraktualisasi secara konkret melalui riset dan analisis literatur, yang mencakup: ensiklopedi-ensiklopedi, kamus-kamus teologi, buku-buku tafsiran, buku-buku teologi dan biblika, jurnal-jurnal teologi dan biblika, serta literatur-literatur lainnya yang berkaitan dengan topik tesis ini.

\section{HASIL DAN PEMBAHASAN}

\section{Kristologi}

Kristus sebagai Mesias Anak Allah yang kekal. Untuk kategori ini, Fee merujuk kepada beberapa bagian dalam Surat Kolose, yaitu: (1) Kolose 1:2-3 dimana Kristus disejajarkan dengan Bapa; (2) Kolose 1:12-17 berbicara tentang keutamaan Kristus sebagai Pribadi yang kekal yang lebih tinggi dan lebih utama dari segala sesuatu; dan (3) Kolose 3:10 sebagai Mesias yang membarui gambar Allah yang telah rusak oleh dosa. ${ }^{11}$

Kristus sebagai Anak Allah dan Penebus yang berinkarnasi. Untuk kategori ini, Fee merujuk kepada beberapa bagian dalam Surat Kolose, yaitu: (1) Kolose 1:18 di mana

\footnotetext{
${ }^{6}$ L. Paul Trudinger, “A Further Brief Note On Colossians 1:24,” The Evangelical Quarterly 45 (1973): 36-
} 38.

${ }^{7}$ Ibid.

${ }^{8}$ Andrew C. Perriman, "The Pattern Of Christ's Suffering: Colossians 1:24 and Philippians 3:10-11," Tyndale Bulletin 42.1 (1991): 62-79.

${ }^{9}$ Richard J. Bauckham, "Colossians 1:24 Again: The Apocalyptic Motiv," The Evangelical Quarterly 47.3 (1975): 168-170.

${ }^{10}$ Ibid.

${ }^{11}$ Gordon D. Fee, Pauline Christology: An Exegetical - Theological Study (Peabody, Massachusetts: Hendrickson Publisher, 2007). 
Kristus disebutkan sebagai Kepala atas segala ciptaan; (2) Kolose 1:19-22 berbicara tentang Kristus sebagai Gambar Allah yang kelihatan yang tuntas mengerjakan karya pendamaian dan penebusan; dan (3) Kolose 2:2-3 di mana Kristus disebut sebagai penyingkapan dari rahasia Allah. Dalam bagian ini, Fee juga menyertakan sebuah eskursus mengenai Kristus sebagai Hikmat Allah. ${ }^{12}$

Kristus sebagai Allah yang ditinggikan/dimuliakan. Untuk kategori ini Fee mengeksegesis beberapa bagian dalam Surat Kolose, yaitu: (1) Kolose 1:10 nasihat Paulus ini dilihat oleh Fee sebagai sesuatu yang mempresuposisikan ke-Tuhan-an Kristus; (2) Kolose 2:6 yang berisi nasihat tetap hidup di dalam Kristus merupakan nasihat yang juga mempresuposisikan ke-Tuhan-an Kristus; (3) Kolose 3:1-4 berbicara tentang Kristus di dalam kekekalan yang "duduk di sebelah kanan Allah"; (4) Kolose 3:13-17 berbicara tentang pemerintahan Kristus atas kehidupan para pengikut-Nya; (5) Kolose 3:18 - 4:1 berbicara tentang ke-Tuhan-an Kristus sebagai dasar dari paraenesis Paulus dalam bagian ini; dan (6) Kolose 1:27-29 di mana Kristus sebut sebagai pengharapan akan kemuliaan. ${ }^{13}$

\section{Eskatologi}

Dalam surat ini, Paulus beberapa kali menandaskan bahwa jemaat di Kolose telah menerima berkat eskatologis, yaitu manfaat dari karya penebusan Kristus $(2: 12-13 ; 3: 1)$. Paulus bahkan menyatakan bahwa mereka "telah dipenuhi di dalam Dia" (2:10). Jemaat di Kolose juga diajarkan bahwa mereka telah "mati bersama Kristus dan dibebaskan dari roh dunia" (2:20) dan telah "dibangkitkan bersama dengan Kristus" (3:1). Mereka harus hidup secara Kristiani sebagai perefleksian dari pemerintahan Kristus atas kehidupan mereka (3:5-17). Paulus menggunakan motif eskatologis yang sudah terealisasi ini sebagai bentuk perlawanan Paulus atas pengajaran visionaris di Kolose yang menekankan tentang ritualritual dan visi-visi spiritual untuk mencapai kepenuhan spiritualitas. Melalui penekananpenekanan ini, Paulus ingin agar jemaat di Kolose menyadari bahwa dasar dari spiritualitas mereka adalah karya Kristus yang sudah sempurna. Mereka telah didamaikan dengan Allah karena penebusan Kristus. ${ }^{14}$

\section{Eklesiologi}

Mengenai signifikansi istilah evkklhsia dalam Surat Kolose. Sumney menjelaskan bahwa keunikan penggunaan istilah ini dalam Surat Kolose adalah cakupan maksudnya yang universal dibandingkan dengan Surat-surat Paulus yang lain. Dalam surat-surat lain, Paulus menggunakan metafora tubuh Kristus untuk jemaat lokal, sementara dalam Surat Kolose, metafora ini digunakan untuk jemaat Kristus yang universal dengan Kristus kosmis

\footnotetext{
12 Ibid.

13 Ibid.

${ }^{14}$ Jerry L. Sumney, Colossians: A Commentary (The New Testament Library; Lousville, Kentucky: Westminster John Knox Press, 2008).
} 
sebagai Kepalanya (1:18). ${ }^{15}$ Ridderbos membantah pembedaan seperti ini. Menurut Ridderbos, memang benar bahwa dalam Surat Kolose dan Efesus, istilah ini digunakan secara eksklusif untuk menyebut jemaat Kristus yang universal, namun tidak berarti bahwa dalam surat-surat lain, Paulus tidak menggunakannya dalam arti ini (Gal. 1:13, 17; bnd. Kis. 9:22; 22:5; 26:11). Gereja yang universal ini merupakan konsep primer dalam eklesiologi Paulus yang bisa dilihat sebagai kontinuasi dari konsep $Q^{e}$ hal-Yahweh dalam PL. 'Evkklhsia bagi Paulus merupakan "sebutan umum bagi persekutuan orang yang percaya kepada Kristus dan dibaptis ke dalam-Nya."16

Signifikansi konsep tubuh-kepala dalam Surat Kolose. Ridderbos menolak konsep "tubuh Kristus" secara harafiah dalam pandangan beberapa teolog Protestan maupun Katholik. Setelah mendiskusikan mengenai konsep tubuh Kristus dalam Surat Roma dan Korintus, Ridderbos memberi perhatian khusus untuk konsep ini dalam Surat Kolose dan Efesus. Menurutnya, dalam Surat Roma dan Korintus, Paulus fokus untuk membahas konsep tubuh Kristus, namun dalam Surat Kolose dan Efesus, Paulus membahas juga konsep tubuh Kristus yang berkaitan erat dengan konsep kekepalaan Kristus. Menurutnya, dalam kedua surat ini, Paulus menggunakan istilah "tubuh" dan "kepala" sebagai dua metafora yang berbeda, bukan satu metafora campuran, namun berkaitan erat. Kekepalaan Kristus dalam hubungan dengan tubuh-Nya bukanlah sebuah konsep fisiologis, melainkan konsep perwakilan dan persekutuan yang berkelanjutan dalam pengertian pneumatis. Roh Kuduslah yang menyucikan dan menyatukan tubuh dengan Kristus. Jadi, konsep Kekepalaan Kristus berhubungan dengan sejarah penebusan [Kristus sebagai klimaks dari janji penebusan Allah bagi umat-Nya] yang menyatukan umat-Nya dengan Dia [konsep koorporat] melalui karya Roh Kudus [Pneumatik]. Itulah sebabnya hubungan Kristus dan gereja disebut juga sebagai "kesatuan Roh". Selanjutnya, Ridderbos mendiskusikan latar belakang konsep ini dengan merujuknya kepada konsep Kristus sebagai Adam kedua. ${ }^{17}$

Signifikansi konsep plhrwma. Konsep plhrwma sangat penting dalam Surat Kolose karena ajaran menyimpang di Kolose yang menolak keutamaan dan kemutlakan Kristus. Dengan menyatakan bahwa Kristus adalah plhrwma Allah, Paulus ingin menandaskan bahwa iman kepada Kristus tidak perlu ditambahkan dengan apa pun [ritual-ritual, asketisme, dsb]. Kristus cukup di dalam diri-Nya sendiri. Atas dasar ini, Paulus juga menyebut gereja sebagai plhrwma-Nya (Ef. 1:23; Kol. 2:10). Bagi Ridderbos, istilah ini merujuk kepada karya Kristus bagi gereja demi pertumbuhan rohani dan kedewasannya. Pertumbuhan dan kedewasaan rohani terkait erat dengan Kristus. Selain mengaitkan konsep ini dengan penolakan Paulus terhadap ajaran menyimpang di Kolose, Ridderbos juga menyatakan bahwa konsep ini memiliki signifikansi yang lebih luas. Dalam kaitan dengan

\footnotetext{
15 Ibid.

${ }^{16}$ Ridderbos, Paulus: Pemikiran Utama Theologinya, 346-249 [kutipan langsung di atas, diambil dari hlm. 346]

${ }^{17}$ Ridderbos, Ibid, 390-408
} 
konsep already but not yet, konsep plhrwma memiliki signifikansi di mana Gereja harus hidup dengan menyatakan Kekepalaan Kristus, sambil berhati-hati bahwa meskipun Kristus telah menaklukkan segala kuasa dunia, namun tidak berarti bahwa kuasa-kuasa itu tidak dapat menyakiti Gereja. ${ }^{18}$

\section{Penderitaan Apostolik Paulus}

"The disciples of Jesus are persecuted because they are identified with his name. The persecution of Jesus continues on in that of his disciples, and they are persecuted like him."19 Penderitaan merupakan bagian integral dari kehidupan para pengikut Kristus. Lalu, apakah signifikansi kesatuan dengan penderitaan Kristus ini dalam memahami apostolisitas Paulus dalam hubungan dengan misinya? Perlu dicatat bahwa kesatuan dengan penderitaan Kristus bukan hanya melandasi pelaksanaan tugas apostolik Paulus. Kesatuan dengan penderitaan Kristus juga merupakan bagian integral yang sudah dinubuatkan oleh Yesus sendiri saat ia menetapkan dan memanggil Paulus sebagai rasulNya. Dan Paulus sendiri memahami dan sadar akan dimensi profetis dari penderitaannya sebagai bagian tidak terpisahkan dari apostolisitasnya (Kis.9:16). Itu sebab Schreiner menyebut topik penderitaan Paulus adalah sesuatu yang sangat vital dalam misinya sebagai rasul untuk bangsa-bangsa lain. ${ }^{20}$

\section{Misi Paulus dan Penderitaannya demi Kristus dan Jemaat}

Dalam studi lebih terbaru yang dilakukan oleh Eckhard J. Schnabel, aktivitas misi Paulus dilakukan dalam enam belas fase, sebagaimana yang akan penulis ringkas sebagai berikut: Damsyik [32 M]; Arabia [32/33 M]; Yerusalem [33/34 M]; Siria dan Kilikia [3442 M]; Antiokhia [42-44 M]; Siprus [45 M]; Galatia selatan [46-47 M]; Pamfilia [47 M]; Makedonia [49-50 M]; Akhaya [50-51 M]; Efesus [52-55]; Ilirikum [56 M]; Yudea [57-59 M]; Roma [60-62 M]; Spanyol [63-64 M?]; dan Kreta [64-65 M?]. Dua fase terakhir yaitu Spanyol dan Kreta bersifat kemungkinan saja karena kedua fase ini hanya berasal dari deduksi terhadap ucapan Paulus mengenai rencananya ke Spanyol dalam Surat Roma dan juga kata-kata Paulus bahwa ia meninggalkan Titus di Kreta. Namun demikian tidak terdapat bukti kuat untuk kedua fase terakhir ini. ${ }^{21}$ Mencermati tempat-tempat yang dikunjungi Paulus ini, Schnabel menyimpulkan bahwa Paulus lebih banyak memusatkan perhatian pada kota-kota penting pada masa itu karena terkait dengan fokus panggilannya yaitu memberitakan Injil bagi orang-orang non Yahudi. Dalam kota-kota besar itu, ia dapatberjumpa dengan populasi orang-orang non Yahudi yang lebih banyak. Karena

\footnotetext{
${ }^{18}$ Herman Ridderbos, Paulus Pemikiran Utama Theologinya (Surabaya: Momentum, 2013).

${ }^{19}$ Scott S. Cunningham, Through Many Tribulation: The Theology Of Persecution In Luke-Acts (JSNTSup 142; Sheffield: Sheffield Academic Press, 1997).

${ }^{20}$ Thomas Screiner, Paul, Apostle Of God Glory In Christ (Downergrove: Intervarsity Press, 2007 ), 87.

${ }^{21}$ Ekhard J. Schnabel, "Paul The Missionary," in Paul's Missionary Methods In His Time And Ours (Downersgrove, Illionis: IVP Academic, 2012), 36-43.
} 
motivasi Paulus adalah "memenangkan sebanyak mungkin orang" bagi Kristus (1Kor. $9: 19-21) .^{22}$

Bagi Paulus, penderitaan-penderitaan yang acap kali terjadi dalam perjalananperjalanan misinya, memiliki makna signifikansi teologis. Dalam 2 Korintus 12:10, ia menyatakan bahwa ia mengalami hal-hal itu u’pe.r Cristou^ ("demi Kristus"). Menurut Barnett, kata-kata Paulus ini berarti "Christ sufferings continues in Paul". ${ }^{23}$ Tetapi, mungkin lebih tepat bila kita memahami hal tersebut sebagaimana yang Paulus kemukakan dalam pasal 1:5, ia dan para rasul lainnya "berlimpah-limpah dalam kesengsaraan Kristus"; "terus-menerus diserahkan kepada maut karena Yesus" (dia. VIhsou/n - 4:11); hidup mereka adalah "bau harum Kristus" (2:15) dan itu berarti ia melihat dirinya sebagai "korban persembahan" bagi Kristus. Sebagaimana Kristus disalibkan bagi umat-Nya (u’pe.r - 5:21), demikian pula Paulus mengalami penderitaan bagi (atau karena kepentingan) jemaat Korintus (u’pe.r - 1:6); ia berkorban bagi jemaat Korintus (u`pe.r 12:15). Dalam surat ini, Paulus memang tidak menggunakan "imitasi" Kristus sebagaimana yang ia gunakan dalam 1 Korintus 11:1, namun ucapan-ucapan yang sudah dikemukakan di atas tidak bisa tidak merepresentasikan gagasan ini. Itulah sebabnya, Barnett menyatakan, "By this identification of himself as a vicarious sufferer, Paul legitimates himself as a true apostle and representative of Christ, as opposed to the opponents who portray themselves as men of power and who say that Paul is a man of weakness [cf. 11:21, 29; 12:9-10]." "24 Dalam Surat Kolose, Paulus dua kali menyatakan bahwa ia menderita "bagi kamu sekalian" [u’pe.r u`mw/n; 1:24; 2:1]. Bila dihubungkan dengan penjelasan di atas, maksud Paulus di sini pasti tidak bisa dilepaskan dari tugasnya sebagai misionaris apostolik. Paulus menerima tugas tersebut dari Kristus maka ia memandang segala bentuk penderitaan yang dialaminya sebagai penderitaan-penderitaan demi Kristus. Paulus juga diutus untuk memberitakan Injil bagi sebanyak mungkin orang, maka penderitaan-penderitaan yang dialaminya juga merupakan penderitaan-penderitaan bagi atau demi orang-orang tersebut.

\section{KESIMPULAN}

secara eklektik, penulis mengamati beragam aspek yang terkait, dan penulis mengemukakan pandangan yang demikian:

$\mathrm{Nu} / \mathrm{n}$ cai,rw evn toi/j paqh,masin u’pe.r u`mw/n merepresentasikan sukacita Paulus atas penderitaan-penderitaannya karena ia melihat signifikansinya bagi jemaat di Kolose. Signifikansi itu dilihat dalam konteks misinya di mana Epafras yang telah berjuang memberitakan Injil bagi mereka dan mengajar mereka, merupakan bagian dari buah

\footnotetext{
${ }^{22}$ Ibid.

${ }^{23}$ Barnett, Paul, Missionary Of Jesus, 177.

${ }^{24}$ Ibid.
} 
pelayanan Paulus. Dalam hal ini, peran Epafras merupakan penghubung antara misi Paulus dan jemaat di Kolose.

avntanaplhrw/ ta. u`sterh,mata tw/n qli,yewn tou/ Cristou/ evn th/| sarki, mou bukan berbicara mengenai penderitaan-penderitannya Kristus, melainkan penderitaan-penderitaan Paulus demi atau karena Kristus. Di sini, penulis memahami tou/ Cristou dalam jenis genitif objektif. Paulus sadar bahwa ia masih akan terus menderita demi Kristus hingga ia meninggal, dan itu berarti penderitaan-penderitaannya yang ia alami sampai dengan saat ia menulis surat ini, bisa dikatakan belum genap. Penderitaan-penderitaan itu akan genap bertepatan dengan kematiannya.

Penderitaan-penderitaan tersebut terjadi bukan hanya memiliki signifikansi bagi jemaat di Kolose, melainkan juga bagi Gereja Tuhan secara universal. Paulus menggunakan istilah u`pe.r tou/sw,matoj auvtou/( o[ evstin h` evkklhsi,a dalam koridor tekad misinya bahwa ia akan terus bergiat untuk mendirikan jemaat Kristus di berbagai tempat, walau untuk itu ia harus menanggung juga banyak penderitaan. Di sini konsep eklesiologis Paulus sebagaimana yang sudah dijelaskan dalam ulasan teologis, sangat kelihatan menonjol.

\section{KEPUSTAKAAN}

Barnett, Paul W. Paul, Missionary Of Jesus. Grand Rapids, Michigan: Eerdmans, 2008.

Bauckham, Richard J. "Colossians 1:24 Again: The Apocalyptic Motiv." The Evangelical Quarterly 47.3 (1975): 168-170.

Bolkestein, M. H. Surat Kiriman Kepada Orang Kolose. Jakarta: BPK Gunung Mulia, 1950.

Cunningham, Scott S. Through Many Tribulation: The Theology Of Persecution In LukeActs. JSNTSup 142; Sheffield: Sheffield Academic Press, 1997.

Fee, Gordon D. Pauline Christology: An Exegetical - Theological Study. Peabody, Massachusetts: Hendrickson Publisher, 2007.

Hooker, Morna D. "Were There False Teachers in Colossae?," In Christi and Spirit in the New Testament. Edited by B. Lindars and S.S. Smaley. Cambridge: Cambridge University Press, 1973.

Perriman, Andrew C. “The Pattern Of Christ's Suffering: Colossians 1:24 and Philippians 3:10-11." Tyndale Bulletin 42.1 (1991): 62-79.

Ridderbos, Herman. Paulus Pemikiran Utama Theologinya. Surabaya: Momentum, 2013.

Roy, Yates. “A Note On Colossians 1:24." The Evangelical Quarterly XLII, no. 2 (1970): 89-92.

Schnabel, Ekhard J. "Paul The Missionary." In Paul's Missionary Methods In His Time And Ours, 36-43. Downersgrove, Illionis: IVP Academic, 2012.

Screiner, Thomas. Paul, Apostle Of God Glory In Christ. Downergrove: Intervarsity Press, 2007.

Sumney, Jerry L. Colossians: A Commentary. The New Testament Library; Lousville, Kentucky: Westminster John Knox Press, 2008.

Thielman, Frank. Theology Of The New Testament: A Canonical And Synthetic Approach. Grand Rapids Michigan: Zondervan, 2005. 
Trudinger, L. Paul. “A Further Brief Note On Colossians 1:24.” The Evangelical Quarterly 45 (1973): 36-38. 